\title{
A Novel Approach to Treatment of Conjunctival Cyst Ablation Using Atmospheric Low-Temperature Plasma
}

This article was published in the following Dove Press journal: Clinical Ophthalmology

\author{
Farhad Nejat' \\ Khosrow Jadidi ${ }^{1}$ \\ Shiva Pirhadi ${ }^{1,2}$ \\ Seyede-Yasamin Adnani ${ }^{\prime}$ \\ Nazanin-Sadat Nabavi ${ }^{1}$ \\ Mohammad Amin Nejat' \\ 'Vision Health Research Center, Semnan \\ University of Medical Sciences, Semnan, \\ Iran; ${ }^{2}$ Department of Biomedical \\ Engineering, Science and Research \\ Branch, Islamic Azad University, Tehran, \\ Iran
}

Purpose: Introducing a new technique to remove the conjunctival cyst using atmospheric low-temperature plasma (ALTP) and assessing its effectiveness.

Patients and Methods: Five eyes with conjunctival cysts were included in this study. The procedure was started by applying a plasma spot on the highest point of the cyst, and then other spots were spirally applied to the base of the cyst to debulk it. The conjunctival cysts were removed using the white handpiece of the plasma generator device (Plexr, GMV s.r.l Grottaferrata, Italy). Refraction, visual acuity, intraocular pressure (IOP), contrast sensitivity (CS), aberrometry, dry eye tests, and ocular surface disease index (OSDI) questionnaire were measured before, one and six months after treatment.

Results: The mean size of the cysts was $3.6 \mathrm{~mm}$ (range 2.1 to $4.8 \mathrm{~mm}$ ). No intraoperative and postoperative complications were observed. Postoperative examinations showed that the patients' cysts were completely healed and recurrence did not occur. Significant changes in visual parameters, IOP, CS, aberrometry and dry eye tests were not observed in the follow-up periods after treatment compared to before. OSDI score decreased after cyst removal.

Conclusion: Our recommended technique using ALTP can be used as a new approach to treating conjunctival cysts. This technique is a simple, office-based, minimally invasive, effective and inexpensive way to remove a cyst.

Keywords: ocular surface disorder, conjunctival cyst, atmospheric low-temperature plasma, sublimation, soft surgery

\section{Introduction}

The Conjunctival cyst is a sac-like lesion with a thin wall that contains clear or sometimes turbid fluid. ${ }^{1,2}$ This lesion can be congenital or acquired. Congenital cysts can remain hidden in the fornix and gradually increase with age. ${ }^{3}$ Acquired cysts can appear after eye trauma, after surgeries such as strabismus, pterygium, scleral buckling, resulting from conjunctivitis such as trachoma, rarely after medication, or even spontaneously. ${ }^{1,2,4-6}$ Most patients with conjunctival cysts are asymptomatic, but others may have symptoms such as mild ocular discomfort, foreign body sensation, corneal astigmatism by compression, dry eye due to unstable tear film, and cosmetic disfigurement, depending on the location and size of the cyst. ${ }^{3,7}$

Cysts may remain stable and asymptomatic and rarely resolve spontaneously. Removal of these lesions if the cyst is large or symptomatic or the patient is dissatisfied with the appearance of the cyst is a selective treatment. The treatment
Correspondence: Farhad Nejat Vision Health Research Center, Semnan, Iran

Tel +989124014938

Email fanejat@yahoo.com 
for cysts is to remove them completely. So far, different methods have been proposed, including aspiration, ${ }^{8}$ excision, ${ }^{2,8,9}$ thermal cautery, ${ }^{4}$ alcohol injection, ${ }^{5}$ argon laser photoablation, ${ }^{10}$ YAG laser, ${ }^{11}$ high-frequency radiowave electrosurgery ${ }^{7}$ and pattern scan laser photocoagulation $^{12}$ to remove the conjunctival cyst. The main complication after treatment is recurrence, which may occur due to the lack of complete separation of the cyst and remain its epithelial cells. Some methods may also damage healthy conjunctiva, sclera, or muscle.

In recent years, plasma technology in medicine has played an important role in performing non-invasive surgeries, and different types of plasma generators have been developed for medical use. ${ }^{13}$ We found the use of atmospheric low-temperature plasma (ALTP) on the surface of the eye is safe in our previous study on an animal model. So, it seems there is the potential to use this type of plasma to treat some ocular surface disorders. ${ }^{14}$ In the following study, we introduce a new and simple plasma-based approach to conjunctival cyst removal.

\section{Patients and Methods}

The study, conducted in conjunction with the Helsinki Declaration, included five patients with conjunctival cysts who visited the Vision Health ophthalmic center in Tehran between November 2018 and August 2019. These patients were nominated for plasma treatment. Patients were explained how we use plasma for cyst removal and the written informed consent was provided by them to have the case details and any accompanying images published. This study has been approved by the ethics committee of Semnan University of Medical Sciences (IR.SEMUMS. REC.1397.198).

All patients underwent slit lamp and fundus examinations before treatment. Also, refraction, uncorrected distance visual acuity (UDVA), corrected distance visual acuity (CDVA), contrast sensitivity (CS), intraocular pressure (IOP), aberrometry, and dry eye tests including tear breakup time (TBUT), tear meniscus height (TMH), corneal fluorescein staining (CFS), 5-minute Schirmer test I and ocular surface disease index (OSDI) for patients were measured. CS, IOP, and aberrometry were performed using the Mars letter contrast sensitivity test (Mars Perceptrix, Chappaqua, New York, USA), rebound tonometer (Icare Finland Oy, Vantaa, Finland) and, raytracing aberrometer (iTrace, Tracey Technologies, Houston, TX, USA), respectively. TBUT, TMH, and CFS were measured using a handheld ocular surface analyzer
(OSA-VET, SBM Sistemi, Torino, Italy). All of these parameters were reassessed one and six months after treatment.

Cyst removal of all patients was performed using the plasma generator device (Plexr, GMV s.r.l Grottaferrata, Italy). Plasma, as the fourth state of matter, is produced by superheating a gas or applying a strong magnetic field to it. ${ }^{15}$ Plasma used in aesthetic medicine is formed at temperatures slightly higher than room temperature and atmospheric pressure. Many of plasma generators in this area create plasma by ionization of the air between the tip of the device and the tissue. The difference in potential between these two points produces an electric arc. ${ }^{16}$ The Plexr that used in this study is a cordless micro-surgical handheld device. It transmits energy to the superficial tissue by generating a small arc and causing it to sublimate. Sublimation is the process by which solid without a transitional liquid phase is directly converted to gas, thus preventing any thermal damage to the surrounding tissue. ${ }^{16}$ The handpiece of the device looks like a thick pen with a needle at the end, which is placed a short distance from where it should be treated. To remove the conjunctival cyst, the white handpiece was used, which produces the plasma with the least amount of power $(0.7$ watts) and close to the tissue.

\section{Surgical Technique}

First, the patient's eye was anesthetized with $0.5 \%$ topical tetracaine (Sina Darou, Tehran, Iran). The plasma-assisted non-invasive surgery (PANIS) method begins with the patient being placed behind the slit lamp. The surgeon uses the white handpiece of the Plexr device to apply a spot to the highest point of the cyst. With this spot, the fluid inside the cyst comes out. Then other spots are applied continuously at the boundary of the lesion until reaching the initial spot or in a spiral path so that the liquid inside the cyst is completely removed and the cyst is debulked. After that, a few spots are applied at the base of the cyst to remove most of the existing epithelial cells and prevent the recurrence. Finally, spots are applied around the cyst to fuse the conjunctival tissue into the underlying layers. There is no limit to the number of spots to reach the final result. All steps of the PANIS method can be seen in Figure 1 and supplemental video. After surgery, the patient was given a medication prescription containing chlobiotic $0.5 \%$ (Sina Darou, Tehran, Iran) every six hours and betamethasone $0.1 \%$ (Sina Darou, Tehran, Iran) every four hours for a week. One week 


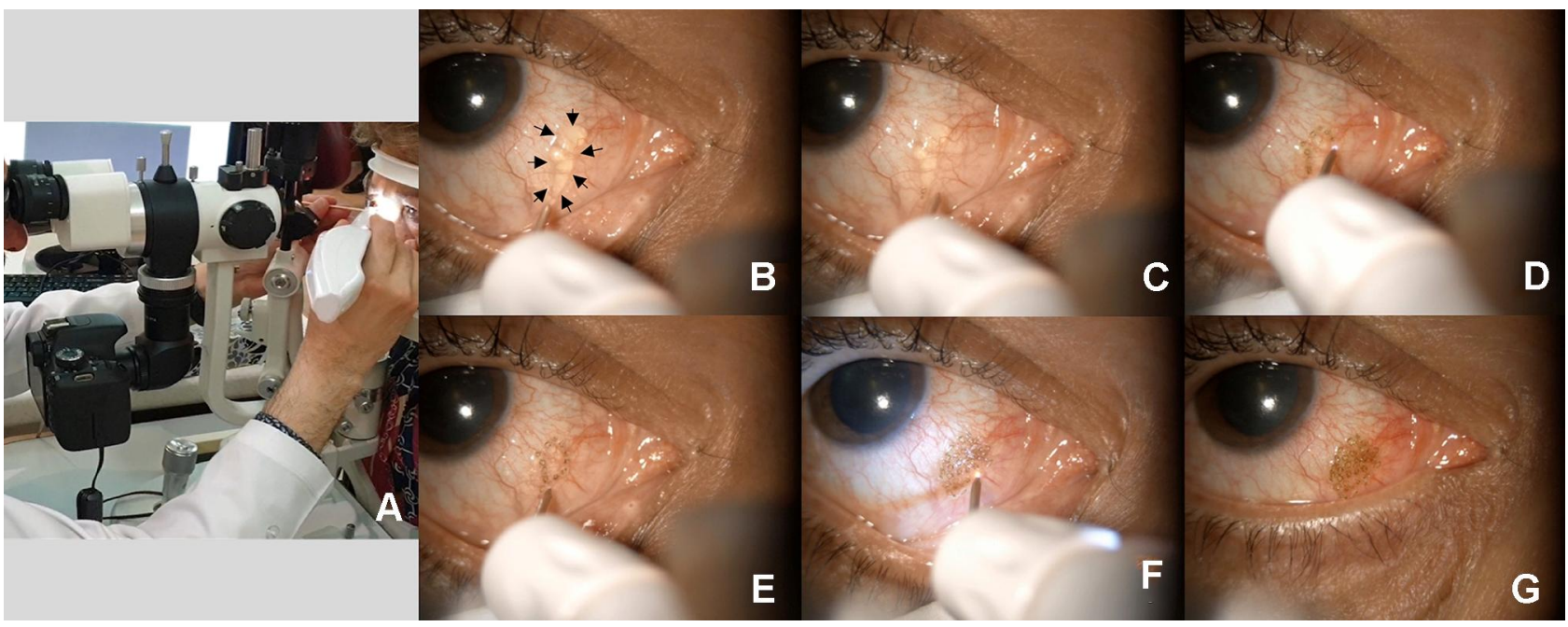

Figure I Steps of the PANIS method to remove the conjunctival cyst. (A) Place the patient behind the slit lamp and use the white handpiece of Plexr device (B) The cyst of patient No. 5 (C) Apply the first spot to drain the fluid of the cyst (D) Apply consecutive spots at the edge of the cyst (E) Continue the spots and reach the initial spot (F) Apply some spots to the base of the cyst to prevent recurrence and around the cyst to fuse conjunctival tissue to the underlying layers (G) End of the surgery and complete removal of the cyst.

after surgery, the chlobiotic drop was discontinued and the dose of betamethasone tapered off over one month. All surgeries were performed by one surgeon (F. N.). Patients were followed up for a day, a week, and one to six months after surgery.

\section{Results}

The study included five patients (5 eyes with idiopathic conjunctival cysts) between 34 and 69 years old. The mean size of the cysts was $3.6 \mathrm{~mm}$ (Range 2.1 to $4.8 \mathrm{~mm}$ ). No intraoperative and postoperative complications were observed. It should be noted that in the first patient with the inferior temporal forniceal cyst position, no effect was observed on the fornix in the form of scarring. None of the patients reported pain during or after surgery. Patient characteristics, cyst size and position, measured visual parameters and dry eye tests can be observed in Table 1. As expected, there were no significant changes in visual parameters (refraction, UCVA, BCVA, CS, total aberration), IOP and dry eye tests (TBUT, TMH, CFS, Schirmer) in the follow-up periods after treatment compared to before. Another parameter examined in this study was the OSDI questionnaire score. This questionnaire is a quick assessment of ocular irritations related to dry eye and its effect on vision-related function. The higher OSDI score indicates greater disability. Table 1 shows that patients' scores decreased after the cyst was removed. This may indicate an improvement in the annoying irritations caused by the cyst. In addition to the questionnaire, the patient's overall satisfaction was questioned. All patients were satisfied with the removal of the cyst.

No recurrence was observed over the six-month follow-up. Slit lamp images of some patients can be seen in Figure 2 before and 6 months after cyst removal. These images show that the cysts have completely healed.

\section{Discussion}

Histologically, the conjunctival cyst includes the wall and the surface composed of non-keratinized squamous epithelium, and goblet cells appear as epithelial cells in its wall. These cells produce mucus secretions inside the cyst cavity. ${ }^{7}$ When the cyst is large or annoying in terms of visually impaired, motility disturbance, foreign body sensation, dry eye, and cosmetic disfigurement, removal is a selective treatment. A review of studies shows that different methods have been proposed to manage conjunctival cysts and each method may have limitations. Simple aspiration is a common office-based procedure for removing the cyst, but because the epithelial cells lining the cyst capsule remain, recurrence is possible. ${ }^{6,10}$ Another method is intracystic injection using sclerosing agents such as doxycycline ${ }^{17}$ and isopropyl alcohol. ${ }^{5}$ The mechanism of action of these agents is an inflammatory or sclerosing reaction ${ }^{9}$ that can lead to protein denaturation, dehydration, cell membrane disruption, loss of cellular function ${ }^{5}$ and prevent the cyst reformation. ${ }^{9}$ Although this method has been successful in eliminating cysts, the extravasation of these substances has the risk of orbital inflammation 


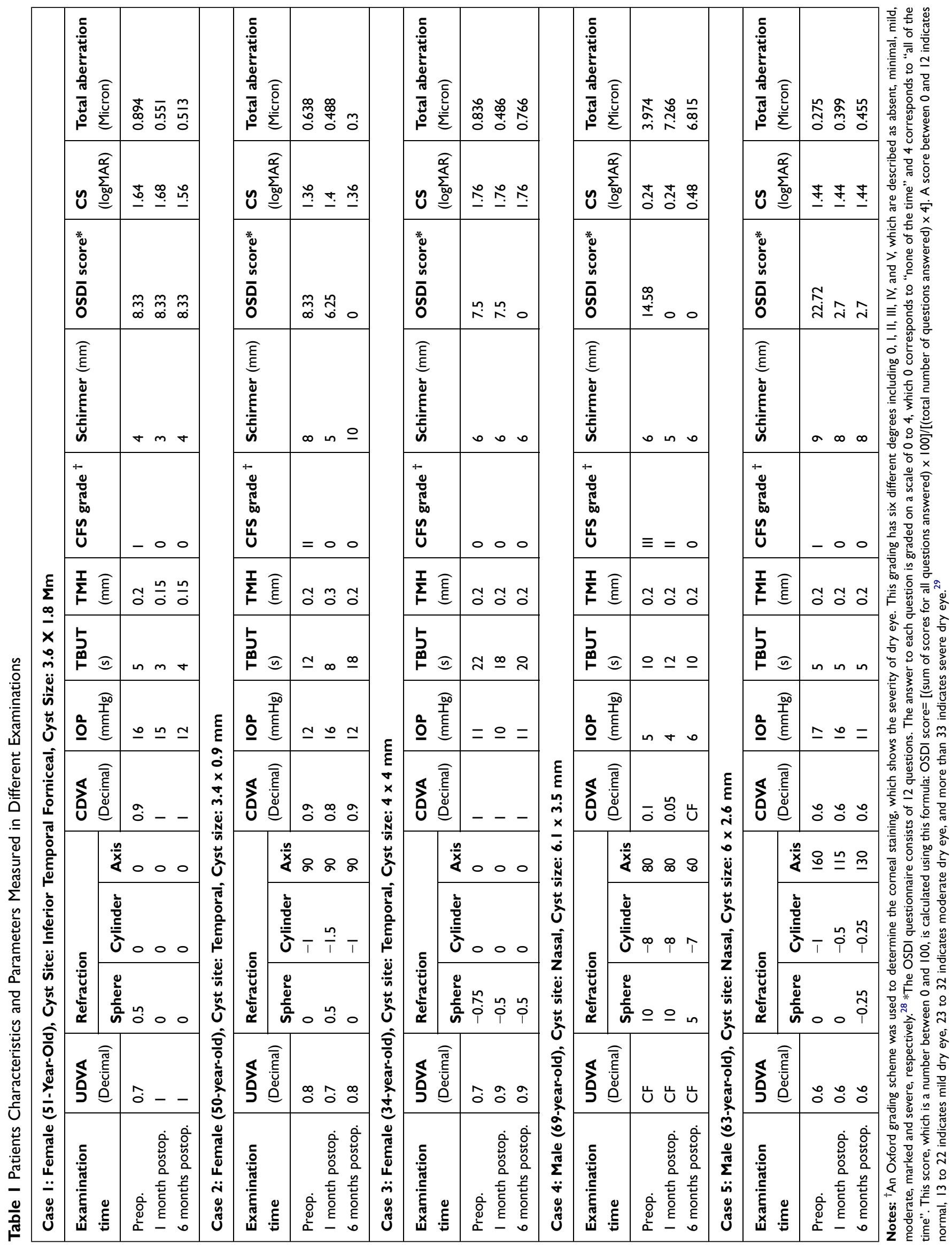




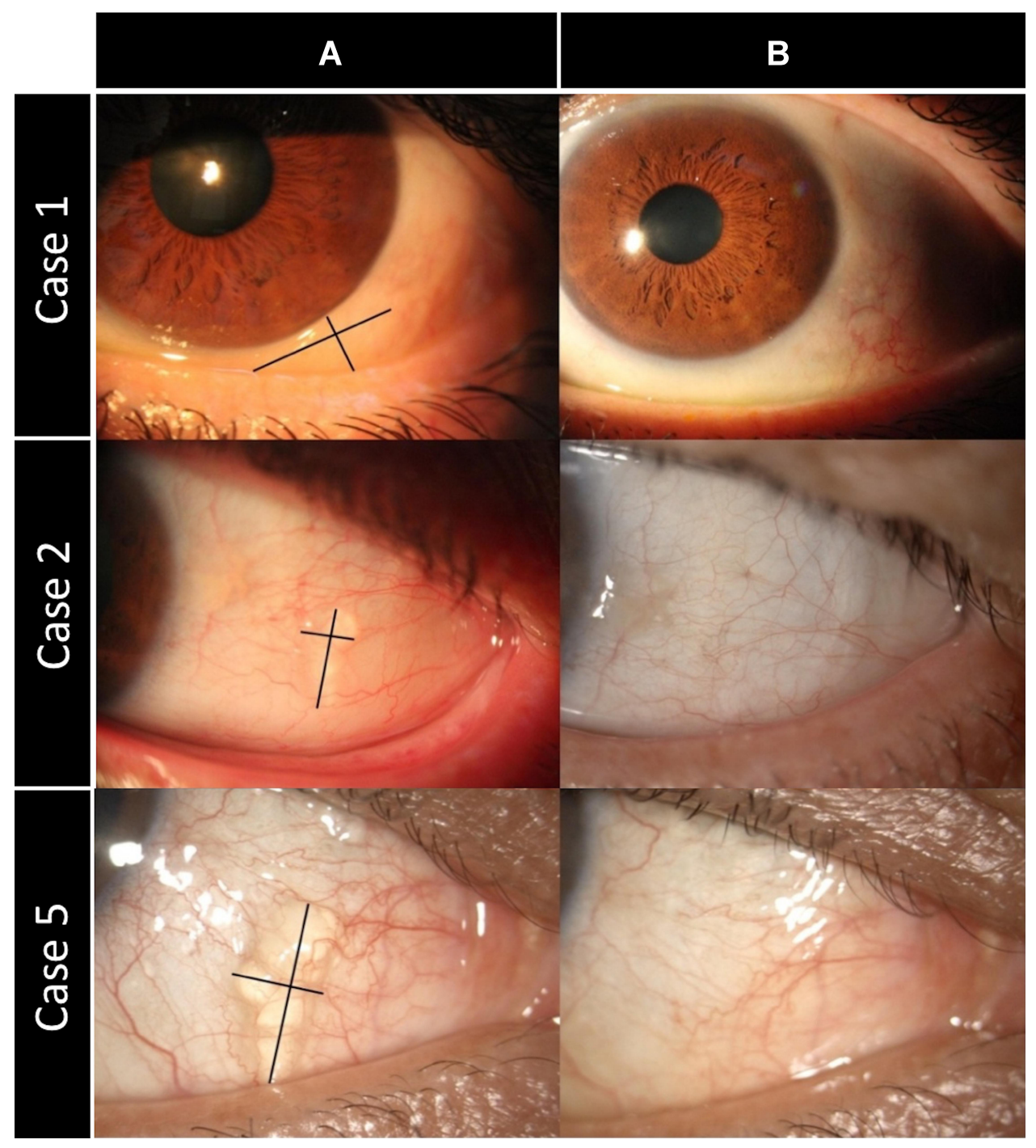

Figure 2 Patient slit lamp images (A) before (B) six months after treatment.

and damage to adjacent tissues such as the cornea. ${ }^{18}$ Thermal cauterization is another effective method in which the surface and then the base of the cyst is cauterized using battery-powered portable thermal cautery at high temperature $\left(2200{ }^{\circ} \mathrm{F}\right){ }^{4}$ In this method, thermal energy may damage muscle and scleral tissue in the form of thermal burns. ${ }^{7}$ Cyst removal using high-frequency radio-wave electrosurgery is another recommended method that reduces damage to surrounding tissues and heat diffusion due to tissue coagulation at lower temperatures than electrocautery. ${ }^{7}$ Lasers have also been used to treat the conjunctival cyst. Applying 5 MJ neodymiumdoped yttrium aluminum garnet (Nd: YAG) laser on the cyst surface is one of the proposed methods ${ }^{11}$ that does not guarantee complete removal of the cyst. ${ }^{7}$ Inspired by the removal of nevus ${ }^{19}$ and pinguecula ${ }^{20}$ using argon laser photocoagulation, collapsing the cyst and then photoablating the base tissue of the cyst has also been performed by this laser. ${ }^{10,21}$ Because the cyst base is in a deeper position than the nevus and pinguecula, an increased amount of laser should be used to access it. This can damage surrounding tissues and increases the pain. ${ }^{7}$ In addition, recurrence has been reported after the removal of the cyst using argon laser. ${ }^{21}$ Another laser that has been suggested to remove the cyst is the pattern scan laser (PASCAL). ${ }^{22}$ PASCAL is a $532-\mathrm{nm}$ frequency-doubled Nd: YAG diode-pumped solid-state laser that has a shorter pulse duration than the argon laser and reduces the amount of damage to adjacent tissues with less penetration and lateral spread of heat. ${ }^{12}$ In this method, an attempt has been made to remove the cyst without damaging its wall through a small laser-created opening. This 
technique has only been recommended for freely movable conjunctival cysts, and the safety and efficacy of this procedure for other types of cysts should be assessed. Finally, the excision can be described as a standard invasive method for treating the cyst in which the conjunctiva near the cyst is incised and the cyst is removed so that the capsule is not damaged. The wound site is then sutured. Because the size of the incision in this surgery is relatively large, more time is needed for hemostasis or suturing. However, another conjunctival cyst may occur during the suturing process. ${ }^{23}$ Also, the visualization of the cyst capsule is difficult due to conjunctival hemorrhage. ${ }^{6}$ Rupture or perforation of the cyst often occurs during surgery, which is an important factor in its complete failure and recurrence. ${ }^{9}$ To visualize and completely remove the cyst, the staining technique of the cyst wall with indocyanine green $^{24}$ and trypan blue ${ }^{25}$ has been suggested. However, in such techniques, in addition to dye costs, there is a risk of staining adjacent healthy tissues and cyst rupture due to excessive injection of dye. ${ }^{7}$ Table 2 summarizes the various methods for removing conjunctival cysts.

To the best of our knowledge, this is the first study to offer a technique to remove the conjunctival cyst using the plasma. This approach has some advantages over the mentioned methods. The first advantage is its simplicity and minimally invasiveness, and it can be done in the office setting compared to the methods that require the operating room. Second, the technique is performed under topical anesthesia and does not require injection or general anesthesia. Third, compared to the excision method, incision, hemostasis, and suture are not required. Fourth, the superficiality of the plasma mechanism of action does not damage deeper tissues such as the sclera and muscle unlike electrocautery and radio-wave electrosurgery. The histopathological results of our previous study on the animal model showed that applying the plasma to the conjunctiva using the low power handpiece of the Plexr device does not cause inflammation and necrosis in the scleral tissue and maintains its integrity. This finding confirms no damage to the deep tissue layers. ${ }^{14}$ Fifth, the Plexr device operates at temperatures slightly higher than room temperature $\left(30-60{ }^{\circ} \mathrm{C}\right)$ and by applying it, the electric current does not pass through the tissue. However, in order to cut, coagulate and fuse the tissue, the electrocautery uses very high temperature and the electrosurgery passes an electrical current through the tissue. The highfrequency electricity is delivered to the tissue through the ends of the electrode and the resistance of the tissue then generates thermal energy within the tissue. ${ }^{7}$ This heat energy can create necrotic tissue around the ablated tissue and delay the healing process. But in the plasma method, the tissue is sublimated when the air particles and ions hit the target surface. In addition, one study has reported the presence of small remnant particles in the subconjunctival area of some patients during the follow-up period after high-frequency electrosurgery. These remnant polytetrafluoroethylene (PTFE) particles may have been detached from the electrode coating of the needle. ${ }^{26}$ Such particles may have the potential to cause inflammation or other systemic side effects. Sixth, the plasma does not create necrotic tissue compared to the proposed methods using lasers. The laser can increase cell temperature, denaturation of proteins and collagen, and necrosis of the cells. ${ }^{27}$ In addition, to prevent recurrence of the cyst, more extensive laser treatment should be performed, which can increase tissue damage and therefore only be possible for small cysts. Unlike lasers, the plasma can also target the base of the cyst without damaging nearby tissues and prevent the recurrence. Finally, the last advantage is the portability of the plexr handpiece compared to other devices such as electrosurgery and laser.

In this study, for the first time, visual variables, dry eye tests, and OSDI questionnaire were assessed before and after the cyst was removed. The results showed that after removal of the cyst, visual parameters and dry eye tests did not change significantly and only the OSDI questionnaire score was improved. Decreased scores may be due to reduced annoying symptoms caused by the cysts or patient satisfaction from the psychometric perspective. The six-month examination also indicated that the cysts had healed and did not recur.

It should be noted that one of the limitations of our study is the small number of patients. Our proposed method is a basic technique and it may need to be modified for various sizes and etiology with different thickness of cyst wall. So, studies with more patients and longer follow-up time are essential. Another limitation is the inability to perform the biopsy of the cyst. Accordingly, when the lesion is suspicious and requires the biopsy, it is best to use methods that extract the tumor without damaging its capsule.

In conclusion, it can be said that the PANIS method is a soft, minimally invasive, low-complication and officebased surgery that can be used to remove the conjunctival cyst safely and effectively. Ophthalmologists can acquire the necessary skills to perform this surgical technique in a short period of time with enough practice and more familiarity with the mentioned plasma technology. 
Table 2 Various Methods for Removing Conjunctival Cysts

\begin{tabular}{|c|c|c|c|c|c|c|c|c|}
\hline $\begin{array}{l}\text { Author (s) } \\
\text { (Year) }\end{array}$ & Methods & $\begin{array}{l}\text { Office- } \\
\text { Based }\end{array}$ & $\begin{array}{l}\text { Type of } \\
\text { Anesthesia }\end{array}$ & $\begin{array}{l}\text { Eyes } \\
\text { (n) }\end{array}$ & $\begin{array}{l}\text { Cyst Size } \\
(\mathrm{mm})\end{array}$ & $\begin{array}{l}\text { Follow-Up } \\
\text { Time } \\
\text { (month) }\end{array}$ & Complications & $\begin{array}{l}\text { Eyes with } \\
\text { Recurrence } \\
\text { (n) }\end{array}$ \\
\hline $\begin{array}{l}\text { Bustros and } \\
\text { Michels } \\
(1984)^{11}\end{array}$ & Nd: YAG laser & Yes & Topical & 1 & $N / M$ & 3 & No & 0 \\
\hline $\begin{array}{l}\text { Hawkins and } \\
\text { Hammin } \\
(200 \mathrm{I})^{4}\end{array}$ & Thermal cautery & Yes & Local & 3 & Small & $\mathrm{I}-2$ & No & 0 \\
\hline Yien et al $(2009)^{6}$ & $\begin{array}{l}\text { Use of sodium } \\
\text { hyaluronate and } \\
\text { indocyanine green } \\
\text { for conjunctival } \\
\text { cyst excision }\end{array}$ & $N / M$ & $N / M$ & I & 4.5 & $N / M$ & $N / M$ & $N / M$ \\
\hline Kothari $(2009)^{5}$ & $\begin{array}{l}\text { Isopropyl alcohol } \\
\text { with paired } \\
\text { injection } \\
\text { technique }\end{array}$ & Yes & Topical & 2 & Small & 9 & $\begin{array}{l}\text { Patient burning } \\
\text { sensation during } \\
\text { exam. }\end{array}$ & 0 \\
\hline Han et al $(2012)^{10}$ & $\begin{array}{l}\text { Argon laser } \\
\text { photoablation }\end{array}$ & $N / M$ & Topical & I & 3 & 6 & No & 0 \\
\hline Eom et al $(2014)^{8}$ & $\begin{array}{l}\text { Sutureless small- } \\
\text { incision } \\
\text { conjunctival } \\
\text { cystectomy }\end{array}$ & $N / M$ & $\begin{array}{l}\text { Topical then } \\
\text { local }\end{array}$ & 4 & $\mathrm{~N} / \mathrm{M}$ & $2-6$ & $N / M$ & 0 \\
\hline Park et al $(2015)^{7}$ & $\begin{array}{l}\text { High-frequency } \\
\text { radio-wave } \\
\text { electrosurgery }\end{array}$ & $N / M$ & Topical & 21 & $N / M$ & $6-14$ & $\begin{array}{l}\text { Mild foreign } \\
\text { body sensation } \\
\text { for two days in } \\
\text { two patients }\end{array}$ & 0 \\
\hline Yang et al $(2017)^{22}$ & $\begin{array}{l}\text { Pattern scan laser } \\
\text { photocoagulation } \\
\text { (PASCAL) }\end{array}$ & $\mathrm{N} / \mathrm{M}$ & Topical & I & 3.5 & 6 & $\begin{array}{l}\text { Minimal amount } \\
\text { of } \\
\text { subconjunctival } \\
\text { hemorrhage }\end{array}$ & 0 \\
\hline $\begin{array}{l}\text { El-Abedin Rajab } \\
\text { and Demer } \\
(2019)^{2}\end{array}$ & $\begin{array}{l}\text { Surgical excision } \\
\text { of conjunctival } \\
\text { retention cyst } \\
\text { using trypan blue } \\
\text { with } \\
\text { methylcellulose }\end{array}$ & No & $\begin{array}{l}2 \text { Local } \\
\text { I General }\end{array}$ & 3 & $N / M$ & 24 & $\mathrm{~N} / \mathrm{M}$ & I \\
\hline Han et al $(2020)^{21}$ & $\begin{array}{l}\text { Modified argon } \\
\text { laser } \\
\text { photoablation }\end{array}$ & Yes & Topical & 17 & $\begin{array}{l}4.8 \\
\text { (range 3-8) }\end{array}$ & $6-28$ & $\begin{array}{l}\text { Hemorrhage in } \\
\text { one patient } \\
\text { during surgery, } \\
\text { two eyes } \\
\text { developed mild } \\
\text { conjunctival } \\
\text { swelling and } \\
\text { foreign body } \\
\text { sensation post- } \\
\text { operative }\end{array}$ & 3 \\
\hline
\end{tabular}

Abbreviations: Cyst size, mean of horizontal and vertical diameters; N/M, not mentioned. 


\section{Disclosure}

The authors report no conflicts of interest in this work.

\section{References}

1. Salagar KM, Pujari MR, Murthy CN. A rare case report of conjunctival cyst. J Clin Diagn Res. 2015;9(11):ND0102. doi:10.7860/JCDR/ 2015/12181.6716

2. El-Abedin Rajab GZ, Demer JL. Long-term results of surgical excision of conjunctival retention cyst using trypan blue with methylcellulose. Am J Ophthalmol Case Rep. 2019;14:28-31. doi:10.1016/j.ajoc.2019.01.010

3. Thatte S, Jain J, Kinger M, Palod S, Wadhva J, Vishnoi A. Clinical study of histologically proven conjunctival cysts. Saudi J Ophthalmol. 2015;29(2):109-115. doi:10.1016/j.sjopt.2014.06.009

4. Hawkins AS, Hamming NA. Thermal cautery as a treatment for conjunctival inclusion cyst after strabismus surgery. J Am Assoc Pediatric Ophthalmol Strabismus. 2001;5(1):48-49. doi:10.1067/ mpa.2001.111779

5. Kothari M. A novel method for management of conjunctival inclusion cysts following strabismus surgery using isopropyl alcohol with paired injection technique. $J$ Am Assoc Pediatric Ophthalmol Strabismus. 2009;13(5):521-522. doi:10.1016/j.jaapos.2009.07.006

6. Yien R, Chan C, Chiu J, et al. Use of sodium hyaluronate and indocyanine green for conjunctival cyst excision. Jpn J Ophthalmol. 2009;53(3):270. doi:10.1007/s10384-008-0654-3

7. Park J, Lee S, Suh E. Removal of conjunctival cyst with high-frequency radio-wave electrosurgery. Canadian J Ophthalmol. 2015;50(5):378-383. doi:10.1016/j.jcjo.2015.07.008

8. Eom Y, Ahn S-E, Kang S-Y, Kim HM, Song JS. Sutureless small-incision conjunctival cystectomy. Canadian J Ophthalmol. 2014;49(1):e17e19. doi:10.1016/j.jcjo.2013.10.002

9. Kim M-S, Lee -J-J, Lee H-J, Lim H-B, Lee S-B. Useful techniques for complete excision of large conjunctival cysts by a transconjunctival approach. Ann Optometry Contact Lens. 2016;15(4):132-138.

10. Han SB, Yang HK, Hyon JY. Removal of conjunctival cyst using argon laser photoablation. Canadian J Ophthalmol. 2012;47(3):e6e8. doi:10.1016/j.jcjo.2012.03.034

11. de Bustros S. Treatment of acquired epithelial inclusion cyst of the conjunctiva using the YAG laser. Am $J$ Ophthalmol. 1984;98:807-808. doi:10.1016/0002-9394(84)90707-4

12. Park YM, Lee J-E, Lee JS. Efficacy of pattern scan laser photocoagulation for superficial conjunctival nevi ablation. Lasers Med Sci. 2016;31(5):1037-1039. doi:10.1007/s10103-016-1915-X

13. Isbary G, Shimizu T, Li Y-F, et al. Cold atmospheric plasma devices for medical issues. Expert Rev Med Devices. 2013;10(3):367-377. doi:10.1586/erd.13.4

14. Nejat F, Nabavi N-S, Nejat M-A, Aghamollaei H, Jadidi K. Safety evaluation of the plasma on ocular surface tissue: an animal study and histopathological findings. Clin Plasma Med. 2019;14:100084. doi:10.1016/j.cpme.2019.100084

Clinical Ophthalmology

\section{Publish your work in this journal}

Clinical Ophthalmology is an international, peer-reviewed journal covering all subspecialties within ophthalmology. Key topics include: Optometry; Visual science; Pharmacology and drug therapy in eye diseases; Basic Sciences; Primary and Secondary eye care; Patient Safety and Quality of Care Improvements. This journal is indexed on PubMed

Submit your manuscript here: https://www.dovepress.com/clinical-ophthalmology-journal
15. Sotiris TG, Nikolaos G, Irini G. Plexr: the revolution in blepharoplasty. Pinnacle Medicine \& Medical Sciences. 2014;1 (5):423-427.

16. King M. Focus on Plasma: the application of plasma devices in aesthetic medicine. PMFA J. 2017;4(5):24-26.

17. Verbeek AM, Ramirez AA, Cruysberg JR, Deutman AF. Recurrent intrascleral cyst after strabismus surgery. Graefe's Archive Clin Exp Ophthalmol. 1996;234(1):S229S231. doi:10.1007/BF02343077

18. Hornblass A, Bosniak S. Orbital cysts following enucleation: the use of absolute alcohol. Ophthalmic Surg Lasers Imaging Retina. 1981;12(2):123-126.

19. Kwon J-W, Jeoung JW, Kim T-I, Lee JH, Wee WR. Argon laser photoablation of conjunctival pigmented nevus. Am J Ophthalmol. 2006;141(2):383-386. doi:10.1016/j.ajo.2005.08.030

20. Shin JY, Khang MH, Han YK, Kwon JW. Case of argon laser photoablation of pinguecula. Clin Experiment Ophthalmol. 2010;38 (7):735-736. doi:10.1111/j.1442-9071.2010.02308.x

21. Han J, Lee S-H, Choi CY, Shin HJ. Treatment outcome of modified argon laser photoablation for conjunctival cysts. Cornea. 2020;39 (4):514-518. doi:10.1097/ICO.0000000000002245

22. Yang HK, Kim M, Lee S-J, Han SB, Hyon JY, Wee WR. Conjunctival cystectomy assisted by pattern scan laser photocoagulation. Military Med Res. 2017;4(1):22. doi:10.1186/ s40779-017-0132-7

23. McCarthy RW, Beyer CK, Dallow RL, Burke JF, Lessell S. Conjunctival cysts of the orbit following enucleation. Ophthalmology. 1981;88(1):30-35. doi:10.1016/S0161-6420(81) 35078-7

24. Kobayashi A, Saeki A, Nishimura A, Segawa Y, Shirao Y, Kawasaki K. Visualization of conjunctival cyst by indocyanine green. Am J Ophthalmol. 2002;133(6):827-828. doi:10.1016/S00029394(02)01416-2

25. Kobayashi A, Sugiyama K. Visualization of conjunctival cyst using Healon V and trypan blue. Cornea. 2005;24(6):759-760. doi:10.1097/01.ico.0000154238.87230.05

26. Kim SH, Kim IT, Choi CY. Evaluation of subconjunctival remnant particles after high-frequency radio-wave electrosurgery for conjunctivochalasis. Korean $J$ Ophthalmol. 2019;33(1):8-15. doi: $10.3341 /$ kjo. 2018.0093

27. Ansari MA, Erfanzadeh M, Mohajerani E. Mechanisms of laser-tissue interaction: II. Tissue thermal properties. J Lasers Med Sci. 2013;4(3):99.

28. Bron AJ, Evans VE, Smith JA. Grading of corneal and conjunctival staining in the context of other dry eye tests. Cornea. 2003;22 (7):640-650. doi:10.1097/00003226-200310000-00008

29. Grubbs JR Jr, Tolleson-Rinehart S, Huynh K, Davis RM. A review of quality of life measures in dry eye questionnaires. Cornea. 2014;33 (2):215. doi:10.1097/ICO.0000000000000038

Central and CAS, and is the official journal of The Society of Clinical Ophthalmology (SCO). The manuscript management system is completely online and includes a very quick and fair peer-review system, which is all easy to use. Visit http://www.dovepress.com/ testimonials.php to read real quotes from published authors. 